\title{
EHMTI-0095. Spreading depression enhances neurogenesis in hippocampus and dentate gyrus
}

\author{
M Lotfinia \\ From 4th European Headache and Migraine Trust International Congress: EHMTIC 2014 \\ Copenhagen, Denmark. 18-21 September 2014
}

\section{Introduction}

Spreading depression (SD) known by transient loss of spontaneous and evoked neuronal activity and changes in ionic, metabolic and hemodynamic characteristics of the brain. Neuronal damage followed by SD, supposed to have a dramatic impression on SD-derived pathologic conditions. We aimed to determine whether SD is able to stimulate persistent neurogenesis.

\section{Methods}

Wistar rat (60-80gr) randomly chosen and $3 \mathrm{~mol} / \mathrm{L} \mathrm{KCl}$ injected for induction of SD. Four weeks after the first injection, all rats were decapitated and the brains removed. The density of mitotic cells, divided cells, and new neurons in the pyramidal cell layer of hippocampal CA1 and CA3 and granular cell layer of dentate gyrus was assessed. We also detect the DNA during the $\mathrm{S}$ phase using Bromodeoxyuridine (BrdU).

\section{Results}

A remarkable increase occurred in the number of BrdUlabeled cells in hippocampal region, detected by immunohistochemistry method. The density of mitotic cells, divided cells, and new neurons in hippocampal CA1 and CA3 and granular cell layer of dentate gyrus also increased.

\section{Conclusion}

We conclude that Spreading depression potentiates to trigger persistent neurogenesis in rat hippocampus.

No conflict of interest.
Published: 18 September 2014

doi:10.1186/1129-2377-15-S1-F15

Cite this article as: Lotfinia: EHMTI-0095. Spreading depression

enhances neurogenesis in hippocampus and dentate gyrus. The Journal of Headache and Pain 2014 15(Suppl 1):F15.
Submit your manuscript to a SpringerOpen ${ }^{\circ}$ journal and benefit from:

- Convenient online submission

- Rigorous peer review

- Immediate publication on acceptance

- Open access: articles freely available online

- High visibility within the field

- Retaining the copyright to your article 